\title{
Systematic Review of Therapeutic Lumbar Transforaminal Epidural Steroid Injections
}

Ricardo M. Buenaventura, MD1, Sukdeb Datta, MD², Salahadin Abdi, MD³, PhD, and Howard S. Smith, MD 4

From: ${ }^{1}$ Pain Relief of Dayton, Centerville, $\mathrm{OH} ;{ }^{2}$ Vanderbilt University Medical Center, Nashville, TN; ${ }^{3}$ University of Miami, Miller School of Medicine, Miami, FL; and ${ }^{4}$ Albany Medical College, Albany, NY.

Dr. Buenaventura is Medical Director, Pain Relief of Dayton,

Centerville, $\mathrm{OH}$; and Clinical Associate Professor, Department of Surgery, Wright State University School of Medicine, Dayton, $\mathrm{OH}$.

Dr. Datta is Director, Vanderbilt University Interventional Pain Program, Associate Professor, Dept. of Anesthesiology,

Vanderbilt University Medical Center, Nashville, TN.

Dr. Abdi is Professor and Chief, Division of Pain Medicine, Department of Anesthesiology, Perioperative Medicine and Pain Management, University of Miami, Miller School of Medicine, Miami, FL.

Dr. Smith is Associate Professor and Academic Director of

Pain Management for Albany Medical College Department of Anesthesiology, Albany, NY.

Address correspondence: Ricardo M. Buenaventura, MD 7244 Far Hills Avenue Centerville, Ohio 45459 E-mail: rbuena@sbcglobal.net

Disclaimer: There was no external funding in the preparation of this manuscript.

Conflict of interest: None.

Manuscript received: $11 / 28 / 2008$ Accepted for publication: $12 / 28 / 2008$

Free full manuscript: www.painphysicianjournal.com
Background: Epidural injection of corticosteroids is one of the most commonly used interventions in managing chronic spinal pain. The transforaminal route to the lumbar epidural space for steroid injection has gained rapid and widespread acceptance for the treatment of lumbar and leg pain. However, there are few well-designed randomized, controlled studies to determine the effectiveness of epidural injections. The role and value of transforaminal lumbar epidural steroid injections is still questioned.

Study Design: A systematic review of transforaminal epidural injection therapy for low back and lower extremity pain.

Objective: To evaluate the effect of transforaminal lumbar epidural steroid injections in managing lumbar (low-back) and sciatica (leg) pain.

Methods: The available literature of lumbar transforaminal epidural injections in managing chronic low back and lower extremity pain was reviewed. The quality assessment and clinical relevance criteria utilized were the Cochrane Musculoskeletal Review Group criteria as utilized for interventional techniques for randomized trials and the criteria developed by the Agency for Healthcare Research and Quality (AHRQ) criteria for observational studies.

The level of evidence was classified as Level I, II, or III based on the quality of evidence developed by the U.S. Preventive Services Task Force (USPSTF).

Data sources included relevant literature of the English language identified through searches of PubMed and EMBASE from 1966 to November 2008, and manual searches of the bibliographies of known primary and review articles.

Outcome Measures: The primary outcome measure was pain relief (short-term relief $=$ up to 6 months and long-term > 6 months). Secondary outcome measures were improvement in functional status, psychological status, return to work, and reduction in opioid intake.

Results: The indicated evidence is Level II- 1 for short-term relief and Level II-2 for long-term relief in managing chronic low back and lower extremity pain. .

Limitations: The limitations of this systematic review include the paucity of literature.

Conclusion: The indicated evidence for transforaminal lumbar epidural steroid injections is Level II-1 for short-term relief and Level II-2 for long-term improvement in the management of lumbar nerve root and low back pain.

Key words: Spinal pain, chronic low back pain, lower extremity pain, transforaminal epidural steroids, radiculopathy, sciatica, steroids, local anesthetic

Pain Physician 2009; 12:1:233-251 
$t$ is estimated that $20 \%$ of the general population may suffer from chronic pain of any type at a given point in time (1). Spinal pain may be the most common type of chronic pain suffered and has a reported lifetime prevalence of $54-80 \%$ (2-10). The economic and social toll of chronic spinal pain and its consequences are great and represent a significant health problem.

Kuslich et al (11) identified intervertebral discs, facet joints, ligaments, facia, muscles, and nerve root dura as tissues capable of transmitting pain in the low back. In the American literature, Mixter and Barr (12) were the first to create widespread interest in the disc as a source of pain with publication of their 1934 hallmark description of the herniated nucleus pulposus. Still today, the pathophysiology of spinal radicular pain is the subject of ongoing research and controversy. In addition to the mechanical component, inflammation of the compressed nerve root is an important factor in the pathophysiology of radicular and discogenic pain (13-21).

Epidural injections for managing chronic low back pain are one of the most commonly performed interventions in the United States (22-33). However, there are several approaches available to access the lumbar epidural space; transforaminal, caudal, and interlaminar $(22,32,33)$.

Substantial differences have been described between these 3 approaches, with the transforaminal approach having the advantage of being target specific and using the smallest volume, fulfilling the aim of reaching the primary site of pathology, namely the ventrolateral epidural space (34-39). Abdi et al (32) showed that the evidence of lumbar transforaminal epidural steroid injections for lumbar nerve root pain was strong for short-term ( $<6$ weeks) and moderate for long-term improvement ( $>6$ weeks). However, they showed limited evidence for transforaminal injections for lumbar radicular pain in post surgery syndrome. Boswell et al (22) also used the same evidence in the development of interventional pain management guidelines. DePalma et al (38) showed that there was moderate evidence in support of selective nerve root blocks in treating painful radicular syndromes.

European guidelines for the management of chronic non-specific low back pain (39) also provided a favorable level of evidence for transforaminal epidural steroids injections. However, multiple other reviews have shown no significant evidence for transforaminal epidural injections as a therapeutic modality $(40,41)$.
In a reassessment of the evidence synthesis of occupational medicine practice guidelines for interventional pain management, Manchikanti et al $(28,42)$ showed Level 1 evidence for both short-term relief ( 6 months or less) and long-term relief (longer than 6 months). Nevertheless, the most effective and beneficial route for the administration of epidural steroids remain controversial; and neither the effectiveness nor the superiority of transforaminal epidural injections has been proven clearly. Further, the underlying mechanism of action of epidurally administered steroid and local anesthetic injections is still not well understood. In addition, a new treatment has been proposed with intraforaminal injection of oxygen-ozone (02-03) $(43,44)$. In fact, this new evidence has shown better relief with the oxygen-ozone combination, than with steroids (43-46).

This systematic review is undertaken to evaluate transforaminal lumbar epidural injections with or without steroids.

\section{Methods}

\section{Literature Search}

A comprehensive literature search of databases was conducted including PubMed and EMBASE from 1966 through November 2008, Cochrane database, Clinical Trial Registry, systematic reviews, narrative reviews, and cross-references to these reviews published in the English language.

The search strategy emphasized chronic low back and lower extremity pain with a focus on lumbar transforaminal epidural injections. Search terminology included lumbar intervertebral disc, disc-related pain, sciatica, lumbar transforaminal epidural injections, lumbar selective nerve root blocks, or lumbar radicular pain.

\section{Selection Criteria}

The review focused on randomized trials, observational studies, and reports of complications. The population of interest was patients suffering with chronic low back and lower extremity pain for at least 3 months. Only lumbar transforaminal epidural injections with or without steroids were evaluated. All of the studies providing appropriate management and with outcome evaluations of 6 months or longer and statistical evaluations were reviewed. Reports without appropriate diagnosis, non-systematic reviews, book chapters, and case reports were excluded. 


\section{Outcome Parameters}

The outcome measures were of documented pain relief at various points in time, functional assessment, and other outcomes including psychological improvement, return to work, and change in opioid intake.

\section{Review Criteria}

Studies were selected if they met the inclusion criteria.

\section{Methodologic Quality Assessment}

The quality of each individual article used in this analysis was assessed by modified Cochrane review criteria with weighted scores (Table 1) (47) for randomized trials and the Agency for Healthcare Research and Quality (AHRQ) quality criteria for assessment of observational studies (Table 2) (48) with consensusbased weighted scoring developed by the guidelines committee of the American Society of Interventional Pain Physicians (ASIPP) utilized in multiple evaluations (28,49-53).

Only the studies scoring at least 50 of 100 on weighted scoring criteria were utilized for analysis.

\section{Clinical Relevance}

Clinical relevance of the included studies was evaluated according to 5 questions recommended by the Cochrane Back Review Group $(27,54)$.

Table 3 shows the clinical relevance questions. Each question was scored positive (+) if the clinical relevance item was met, negative $(-)$ if the item was not met, and unclear (?) if data were not available to answer the question.

Table 1. Modified and weighted Cochrane methodologic quality assessment criteria.

\begin{tabular}{|c|c|c|}
\hline & CRITERION & $\begin{array}{c}\text { Weighted } \\
\text { Score (points) }\end{array}$ \\
\hline & population & 35 \\
\hline A & Homogeneity & 2 \\
\hline B & Comparability of relevant baseline characteristics & 5 \\
\hline $\mathrm{C}$ & Randomization procedure adequate & 4 \\
\hline $\mathrm{D}$ & Drop-outs described for each study group separately & 3 \\
\hline $\mathrm{E}$ & $<20 \%$ loss for follow-up & 2 \\
\hline & $<10 \%$ loss for follow-up & 2 \\
\hline $\mathrm{F}$ & $>50$ subject in the smallest group & 8 \\
\hline & $>100$ subjects in the smallest group & 9 \\
\hline & rentions & 25 \\
\hline G & Interventions included in protocol and described & 10 \\
\hline $\mathrm{H}$ & Pragmatic study & 5 \\
\hline I & Co-interventions avoided or similar & 5 \\
\hline $\mathrm{J}$ & Placebo-controlled & 5 \\
\hline & & 30 \\
\hline K & Patients blinded & 5 \\
\hline $\mathrm{L}$ & Outcome measures relevant & 10 \\
\hline M & Blinded outcome assessments & 10 \\
\hline $\mathrm{N}$ & Follow-up period adequate & 5 \\
\hline & presentation and analysis & 10 \\
\hline $\mathrm{O}$ & Intention-to-treat analysis & 5 \\
\hline $\mathrm{P}$ & Frequencies of most important outcomes presented for each treatment group & 5 \\
\hline & TOTAL SCORE & 100 \\
\hline
\end{tabular}

Adapted from Koes BW et al. Efficacy of epidural steroid injections for low-back pain and sciatica: A systematic review of randomized clinical trials. Pain 1995; 63:279-288 (47). 
Table 2. Modified AHRQ quality assessment criteria for observational studies.

\begin{tabular}{|c|c|}
\hline CRITERION & Weighted Score (points) \\
\hline 1. Study Question & 2 \\
\hline \multicolumn{2}{|l|}{ - Clearly focused and appropriate question } \\
\hline 2. Study Population & 8 \\
\hline - Description of study population & 5 \\
\hline - Sample size justification & 3 \\
\hline 3. Comparability of Subjects & 22 \\
\hline - Specific inclusion/exclusion criteria for all groups & 5 \\
\hline - Criteria applied equally to all groups & 3 \\
\hline - Comparability of groups at baseline with regard to disease status and prognostic factors & 3 \\
\hline - Study groups comparable to non-participants with regard to confounding factors & 3 \\
\hline - Use of concurrent controls & 5 \\
\hline - Comparability of follow-up among groups at each assessment & 3 \\
\hline 4. Exposure or Intervention & 11 \\
\hline - Clear definition of exposure & 5 \\
\hline - Measurement method standard, valid and reliable & 3 \\
\hline - Exposure measured equally in all study groups & 3 \\
\hline 5. Outcome measures & 20 \\
\hline - Primary/secondary outcomes clearly defined & 5 \\
\hline - Outcomes assessed blind to exposure or intervention & 5 \\
\hline - Method of outcome assessment standard, valid and reliable & 5 \\
\hline - Length of follow-up adequate for question & 5 \\
\hline 6. Statistical Analysis & 19 \\
\hline - Statistical tests appropriate & 5 \\
\hline - Multiple comparisons taken into consideration & 3 \\
\hline - Modeling and multivariate techniques appropriate & 2 \\
\hline - Power calculation provided & 2 \\
\hline - Assessment of confounding & 5 \\
\hline - Dose-response assessment if appropriate & 2 \\
\hline 7. Results & 8 \\
\hline - Measure of effect for outcomes and appropriate measure of precision & 5 \\
\hline - Adequacy of follow-up for each study group & 3 \\
\hline 8. Discussion & 5 \\
\hline \multicolumn{2}{|l|}{ - Conclusions supported by results with possible biases and limitations taken into consideration } \\
\hline 9. Funding or Sponsorship & 5 \\
\hline \multicolumn{2}{|l|}{ - Type and sources of support for study } \\
\hline TOTAL SCORE & 100 \\
\hline
\end{tabular}

Adapted and modified from West S et al. Systems to Rate the Strength of Scientific Evidence, Evidence Report, Technology Assessment No. 47. AHRQ Publication No. 02-E016 (48). 
Table 3. Clinical relevance questions.

\begin{tabular}{|ll||}
\hline A) & Are the patients described in detail so that you can decide whether they are comparable to those that you see in your practice? \\
\hline B) & Are the interventions and treatment settings described well enough so that you can provide the same for your patients? \\
\hline C) & Were all clinically relevant outcomes measured and reported? \\
\hline D) & Is the size of the effect clinically important? \\
\hline E) & Are the likely treatment benefits worth the potential harms? \\
\hline
\end{tabular}

Source: Staal JB et al. Injection therapy for subacute and chronic low-back pain. Cochrane Database Syst Rev 2008; 3:CD001824 (27).

Table 4. Quality of evidence developed by USPSTF.

\begin{tabular}{|c|l||}
\hline I: & Evidence obtained from at least one properly randomized controlled trial \\
\hline II-1: & Evidence obtained from well-designed controlled trials without randomization \\
\hline II-2: & $\begin{array}{l}\text { Evidence obtained from well-designed cohort or case-control analytic studies, preferably from more than one } \\
\text { center or research group }\end{array}$ \\
\hline II-3: & $\begin{array}{l}\text { Evidence obtained from multiple time series with or without the intervention. Dramatic results in uncontrolled } \\
\text { experiments (such as the results of the introduction of penicillin treatment in the 1940s) could also be regarded } \\
\text { as this type of evidence }\end{array}$ \\
\hline III: & $\begin{array}{l}\text { Opinions of respected authorities, based on clinical experience descriptive studies and case reports or reports of } \\
\text { expert committees }\end{array}$ \\
\hline \hline
\end{tabular}

Adapted from the U.S. Preventive Services Task Force (USPSTF) (61).

In the recent Cochrane review of "Injection Therapy for Subacute and Chronic Low Back Pain" (27) the authors considered $20 \%$ improvement in pain scores (55) and $10 \%$ improvement in functioning outcomes (56) to be clinically important. The current study utilized stricter criteria than general systematic reviews and previous systematic reviews. Any relief of 6 months or less was considered as short-term, whereas Cochrane reviews (27) and others have considered 6 weeks as short-term and longer than 6 weeks as long-term. We also utilized methodologic quality assessment criteria (27) for minimum inclusion, thus this current systematic review is expected to provide robust results with stricter criteria. However, in contrast to many other systematic reviews, we have not excluded observational studies, but included only quality observational studies with scores of 50 or more on a scale of 0 - 100 based on the AHRQ criteria. This inclusion improves the generalizability of the systematic review and the intervention to the population (57-60).

\section{Analysis of Evidence}

Analysis was conducted using 5 levels of evidence, ranging from Level I to III with 3 subcategories in Level II, as illustrated in Table 4 (61) developed by the U.S. Preventive Services Task Force (USPSTF).

\section{Recommendations}

Grading recommendations were based on Guyatt et al's criteria as illustrated in Table 5 (62).

\section{Outcome of the Studies}

In the randomized trials, a study was judged to be positive if the transforaminal epidural injection therapy was clinically relevant and effective, either with a placebo control or active control. This indicates that the difference in effect for primary outcome measure was statistically significant on the conventional $5 \%$ level. In a negative study, no difference between the study treatments or no improvement from baseline was identified. Further, the outcomes were judged at the reference point with positive or negative results reported at 3 months, 6 months, and one-year.

For observational studies, a study was judged to be positive if the epidural injection therapy was effective, with outcomes reported at the reference point with positive or negative results at 3 months, 6 months, and one-year. However, observational studies were only included in the evidence synthesis if there were less than 4 randomized trials meeting inclusion criteria for evidence synthesis. 
Table 5. Grading recommendations.

\begin{tabular}{|c|c|c|c|}
\hline $\begin{array}{l}\text { Grade of Recommendation/ } \\
\text { Description }\end{array}$ & $\begin{array}{l}\text { Benefit vs Risk and } \\
\text { Burdens }\end{array}$ & $\begin{array}{l}\text { Methodological Quality of } \\
\text { Supporting Evidence }\end{array}$ & Implications \\
\hline $\begin{array}{l}1 \mathrm{~A} / \text { strong recommendation, high- } \\
\text { quality evidence }\end{array}$ & $\begin{array}{l}\text { Benefits clearly outweigh } \\
\text { risk and burdens, or vice } \\
\text { versa }\end{array}$ & $\begin{array}{l}\text { RCTs without important limitations } \\
\text { or overwhelming evidence from } \\
\text { observational studies }\end{array}$ & $\begin{array}{l}\text { Strong recommendation, } \\
\text { can apply to most patients in } \\
\text { most circumstances without } \\
\text { reservation }\end{array}$ \\
\hline $\begin{array}{l}1 \mathrm{~B} / \text { strong recommendation, moder- } \\
\text { ate quality evidence }\end{array}$ & $\begin{array}{l}\text { Benefits clearly outweigh } \\
\text { risk and burdens, or vice } \\
\text { versa }\end{array}$ & $\begin{array}{l}\text { RCTs with important limitations } \\
\text { (inconsistent results, methodologi- } \\
\text { cal flaws, indirect, or imprecise) or } \\
\text { exceptionally strong evidence from } \\
\text { observational studies }\end{array}$ & $\begin{array}{l}\text { Strong recommendation, } \\
\text { can apply to most patients in } \\
\text { most circumstances without } \\
\text { reservation }\end{array}$ \\
\hline $\begin{array}{l}1 \mathrm{C} / \text { strong recommendation, low- } \\
\text { quality or very low-quality evidence }\end{array}$ & $\begin{array}{l}\text { Benefits clearly outweigh } \\
\text { risk and burdens, or vice } \\
\text { versa }\end{array}$ & Observational studies or case series & $\begin{array}{l}\text { Strong recommendation but } \\
\text { may change when higher qual- } \\
\text { ity evidence becomes available }\end{array}$ \\
\hline $\begin{array}{l}\text { 2A/weak recommendation, high- } \\
\text { quality evidence }\end{array}$ & $\begin{array}{l}\text { Benefits closely balanced } \\
\text { with risks and burden }\end{array}$ & $\begin{array}{l}\text { RCTs without important limitations } \\
\text { or overwhelming evidence from } \\
\text { observational studies }\end{array}$ & $\begin{array}{l}\text { Weak recommendation, best } \\
\text { action may differ depending } \\
\text { on circumstances or patients' } \\
\text { or societal values }\end{array}$ \\
\hline $\begin{array}{l}2 \mathrm{~B} / \text { weak recommendation, moderate- } \\
\text { quality evidence }\end{array}$ & $\begin{array}{l}\text { Benefits closely balanced } \\
\text { with risks and burden }\end{array}$ & $\begin{array}{l}\text { RCTs with important limitations } \\
\text { (inconsistent results, methodologi- } \\
\text { cal flaws, indirect, or imprecise) or } \\
\text { exceptionally strong evidence from } \\
\text { observational studies }\end{array}$ & $\begin{array}{l}\text { Weak recommendation, best } \\
\text { action may differ depending } \\
\text { on circumstances or patients' } \\
\text { or societal values }\end{array}$ \\
\hline $\begin{array}{l}2 \mathrm{C} / \text { weak recommendation, low-qual- } \\
\text { ity or very low-quality evidence }\end{array}$ & $\begin{array}{l}\text { Uncertainty in the esti- } \\
\text { mates of benefits, risks, } \\
\text { and burden; benefits, risk, } \\
\text { and burden may be closely } \\
\text { balanced }\end{array}$ & Observational studies or case series & $\begin{array}{l}\text { Very weak recommendations; } \\
\text { other alternatives may be } \\
\text { equally reasonable }\end{array}$ \\
\hline
\end{tabular}

Adapted from Guyatt $\mathrm{G}$ et al. Grading strength of recommendations and quality of evidence in clinical guidelines. Report from an American College of Chest Physicians task force. Chest 2006; 129:174-181 (62).

\section{Results}

A literature search was carried out for lumbar transforaminal epidural injections as shown in Fig. 1.

Our search strategy yielded multiple manuscripts evaluating the effectiveness of lumbar transforaminal epidural injections with or without steroids (43-45,63-101).

\section{Methodologic Quality Assessment}

\section{Randomized Trials}

Of the 11 randomized trials, 7 studies met the inclusion criteria $(45,68,72,83,90,92,94)$. Four studies were excluded from the analysis for short-term followup and other deficiencies $(43,73,89,94)$. Even though follow-up was adequate, Gallucci et al (43) was excluded because intradiscal injections were combined with transforaminal epidurals, thus negating the individual effect to be evaluated.

Methodological quality assessment criteria are illustrated in Table 6 . There were 2 studies with duplicate presentations: Riew et al $(83,94)$ and Karppinen et al $(72,90)$. Thus, methodologic quality assessment was carried out for a total of 5 studies $(45,68,72,83,90,92,94)$ with scores ranging from 44 to 86 . The study by Devulder (68) with a score of 44 failed to meet the methodologic quality assessment criteria. 


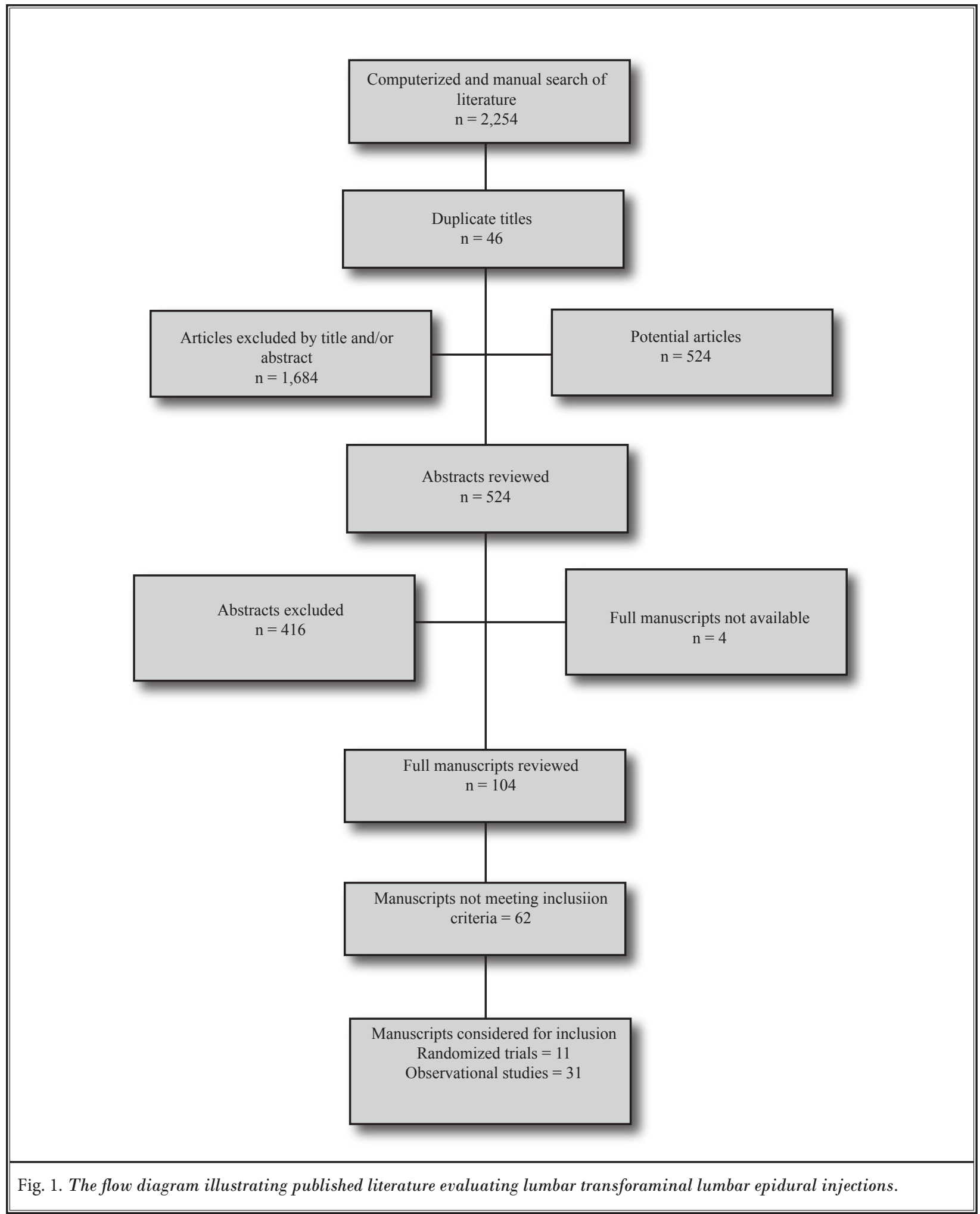


Table 6. Methodological assessment of randomized clinical trials evaluating the effectiveness of lumbar transforaminal epidural injections.

\begin{tabular}{|c|c|c|c|c|c|c|c|}
\hline \multicolumn{2}{|c|}{ "CRITERION } & $\begin{array}{c}\text { WEIGHTED } \\
\text { SCORE } \\
\text { (points) }\end{array}$ & $\begin{array}{c}\text { Riew et al } \\
(\mathbf{8 3}, 94)\end{array}$ & $\begin{array}{l}\text { Devulder } \\
\quad(\mathbf{6 8}) *\end{array}$ & $\begin{array}{l}\text { Vad et al } \\
\quad(92)\end{array}$ & $\begin{array}{c}\text { Karppinen } \\
\text { et al } \\
(\mathbf{7 2 , 9 0 )} \\
\end{array}$ & $\begin{array}{l}\text { Jeong et } \\
\text { al (45) }\end{array}$ \\
\hline \multicolumn{8}{|c|}{ Study population } \\
\hline A & Homogeneity & 2 & 2 & 2 & 2 & 2 & 2 \\
\hline B & $\begin{array}{l}\text { Comparability of relevant baseline } \\
\text { characteristics }\end{array}$ & 5 & 5 & 5 & 3 & 5 & 5 \\
\hline $\mathrm{C}$ & Randomization procedure adequate & 4 & 4 & 4 & 1 & 4 & 4 \\
\hline $\mathrm{D}$ & $\begin{array}{l}\text { Drop-outs described for each study group } \\
\text { separately }\end{array}$ & 3 & 3 & 3 & 3 & 3 & 3 \\
\hline \multirow[t]{2}{*}{$\mathrm{E}$} & $<20 \%$ loss for follow-up & 2 & 2 & 2 & 2 & 2 & 2 \\
\hline & $<10 \%$ loss for follow-up & 2 & 2 & 2 & 2 & 2 & 2 \\
\hline \multirow[t]{2}{*}{$\mathrm{F}$} & $>50$ subject in the smallest group & 8 & - & - & - & 8 & - \\
\hline & $>100$ subjects in the smallest group & 9 & - & - & - & - & - \\
\hline \multicolumn{8}{|c|}{ Interventions } \\
\hline G & $\begin{array}{l}\text { Interventions included in protocol and } \\
\text { described }\end{array}$ & 10 & 10 & 10 & 10 & 10 & 10 \\
\hline $\mathrm{H}$ & Pragmatic study & 5 & 5 & 5 & 5 & - & 5 \\
\hline I & Co-interventions avoided or similar & 5 & 5 & 5 & 5 & 5 & 5 \\
\hline $\mathrm{J}$ & Placebo-controlled & 5 & - & - & - & 5 & - \\
\hline \multicolumn{8}{|c|}{ Effect } \\
\hline $\mathrm{K}$ & Patients blinded & 5 & 5 & 1 & - & 5 & 5 \\
\hline $\mathrm{L}$ & Outcome measures relevant & 10 & 10 & 2 & 10 & 10 & 10 \\
\hline $\mathrm{M}$ & Blinded outcome assessments & 10 & 5 & 1 & 5 & 10 & - \\
\hline $\mathrm{N}$ & Follow-up period adequate & 5 & 5 & 2 & 5 & 5 & 5 \\
\hline \multicolumn{8}{|c|}{ Data-presentation and analysis } \\
\hline $\mathrm{O}$ & Intention-to-treat analysis & 5 & 5 & - & 5 & 5 & - \\
\hline$P$ & $\begin{array}{l}\text { Frequencies of most important outcomes } \\
\text { presented for each treatment group }\end{array}$ & 5 & 5 & - & 5 & 5 & 5 \\
\hline \multicolumn{2}{|r|}{$\begin{array}{r}\text { TOTAL SCORE } \\
\end{array}$} & 100 & 73 & 44 & 63 & 86 & 63 \\
\hline
\end{tabular}

* Failed to meet exclusion criteria. Methodological criteria and scoring adapted from Koes BW et al. Efficacy of epidural steroid injections for lowback pain and sciatica: A systematic review of randomized clinical trials. Pain 1995; 63:279-288 (47).

Only 2 of the 4 studies had groups of patients greater than 50 participants $(45,72,90)$. Only one study was placebo-controlled $(72,90)$. However, the placebo solution in this study was injected over the nerve root as in the intervention group with local anesthetic and steroid. This may not be considered as a true placebo control as we are not aware of the effects of the injection of sodium chloride solution into the epidural space or over the nerve roots. The patients were not blinded in one of the studies (92). Three $(72,83,90,92,94)$ of the 5 studies included an intention to treat analysis.

\section{Clinical Relevance Assessment}

All 4 of the included studies met clinical relevance criteria $(45,72,83,90,92,94)$. Clinical relevance criteria was evaluated as shown in Table 7 for 4 randomized trials.

\section{Study Population}

The populations evaluated in the 4 studies were consistent in that they included both back and leg pain patients and evidence of nerve root compression on imaging studies. Some studies did exclude patients with prior lumbar spine surgery, while the others did not $(83,94)$. 
Table 7. Clinical relevance of randomized clinical trials evaluating the effectiveness of lumbar transforaminal epidural injections.

\begin{tabular}{|c|c|c|c|c|}
\hline & $\begin{array}{c}\text { Riew et al } \\
(83,94)\end{array}$ & $\begin{array}{c}\text { Vad et al } \\
(92)\end{array}$ & $\begin{array}{c}\text { Karppinen et al } \\
(72,90)\end{array}$ & $\begin{array}{c}\text { Jeong et al } \\
(45)\end{array}$ \\
\hline $\begin{array}{l}\text { A) Are the patients described in detail so that you can decide whether } \\
\text { they are comparable to those that you see in your practice? }\end{array}$ & + & + & + & + \\
\hline $\begin{array}{l}\text { B) Are the interventions and treatment settings described well enough } \\
\text { so that you can provide the same for your patients? }\end{array}$ & + & + & + & + \\
\hline C) Were all clinically relevant outcomes measured and reported? & + & + & + & + \\
\hline D) Is the size of the effect clinically important? & + & + & + & + \\
\hline E) Are the likely treatment benefits worth the potential harms? & + & + & + & + \\
\hline TOTAL CRITERIA MET & $5 / 5$ & $5 / 5$ & $5 / 5$ & $5 / 5$ \\
\hline
\end{tabular}

+ = positive; - = negative

Scoring adapted from Staal JB et al. Injection therapy for subacute and chronic low-back pain. Cochrane Database Syst Rev 2008; 3:CD001824 (27).

\section{Cost Analysis}

Only Karppinen mentioned any kind of cost analysis (72). At the 4-week follow-up period the patients who received methylprednisolone transforaminally utilized fewer therapy visits and less drugs resulting in significantly lower costs. At all other times there was no significant cost difference in the groups. No other study performed any kind of cost analysis.

\section{Observational Studies}

After methodologic quality assessment, 4 randomized trials met the inclusion criteria for evidence synthesis, thus observational studies were not evaluated for methodologic assessment quality criteria or evidence synthesis.

\section{Study Characteristics}

Table 8 illustrates the details of the randomized trials studying the effectiveness of lumbar transforaminal epidural steroids injection.

Jeong et al (45) essentially compared transforaminal epidural injections to themselves and only altered the level (preganglionic vs. ganglionic) injected. The question they sought to answer was where it is best to inject; at the site where the disc is contacting the presumed affected nerve or at the foramen where that nerve exits. If a patient has a disk herniation at L4-5 that contacts the $L 5$ nerve root then one could perform a pre-ganglionic injection at the L4-5 foraminal level or a ganglionic injection at the L5-S1 level. Jeong's group performed 239 transforaminal injections, 127 ganglionic and 112 pre-ganglionic. The drugs injected were triamcinolone and bupivacaine. They did assess patient reported pain scores and degree of improvement. At the short-term the pre-ganglionic injection group did better than the ganglionic group. At long-term follow-up there was no statistically significant difference between the groups but a majority of the patients in both groups rated their outcomes as good to excellent (79\% at short-term and $63.9 \%$ at long-term). The authors concluded that the implication for patient care is that a pre-ganglionic approach may be considered an alternative to a ganglionic approach when the needle tip cannot be advanced adjacent to the neuroforamen or adequate amounts of the drug cannot be injected into the epidural space through the neuroforamen owing to severe neuroforaminal stenosis. However, the use of transforaminal epidural steroids injection with a pre-ganglionic (99 of 112 patients) approach is more effective than a ganglionic (90 of 127 patients) approach at short-term follow-up and is almost as effective (64 of 106 patients) as a ganglionic approach (78 of 116 patients) at mid-term follow-up.

Karppinen et al evaluated transforaminal epidural steroid injections in patients with sciatica (90). Eighty patients received transforaminal epidural injections of methylprednisolone and bupivacaine and another 80 received saline injections via a transforaminal injection. Pain and Oswestry scores were recorded. Both groups showed improvement with the steroid group doing better than the saline at 2 weeks and the saline group doing better at the 3 and 6 month points. Interestingly, the steroid and local anesthetic infiltration seemed to be associated with a rebound phenomenon at 3 and 6 months. This was manifested by little or no improvement in pain and disability between 3 and 6 
Table 8. Details of randomized trials studying the effectiveness of lumbar transforaminal epidural steroid injections.

\begin{tabular}{|c|c|c|c|c|c|}
\hline $\begin{array}{l}\text { Studyl } \\
\text { Methods }\end{array}$ & Participants & Intervention(s) & Outcome(s) & Result(s) & $\begin{array}{l}\text { Conclusion(s) } \\
\text { Short-term } \\
\text { relief } \leq 6 \mathrm{mos} \\
\text { Long-term } \\
\text { relief }>6 \mathrm{mos} \\
\end{array}$ \\
\hline $\begin{array}{l}\text { Karppinen et } \\
\text { al 2001/2001 } \\
(72,90) \\
\text { Randomized, } \\
\text { double-blind } \\
\text { trial }\end{array}$ & $\begin{array}{l}160 \text { consecutive, eligible pts } \\
\text { with sciatica with unilat- } \\
\text { eral symptoms of } 1 \text { to } 6 \text { mos. } \\
\text { duration. None of the pts had } \\
\text { undergone surgery. }\end{array}$ & $\begin{array}{l}\text { Experimental: local } \\
\text { anesthetic and methyl- } \\
\text { prednisolone. Control: } \\
\text { normal saline. }\end{array}$ & $\begin{array}{l}\text { Timing: } 2 \text { wks, } 4 \\
\text { wks, } 3 \text { mos., } 6 \text { mos., } \\
\text { and } 1 \text { yr. } \\
\text { Outcome measures: } \\
\text { Pain relief, sick leave, } \\
\text { medical costs, and } \\
\text { future surgery. } \\
\text { A subgroup analysis } \\
\text { and cost effective- } \\
\text { ness was performed } \\
\text { (309). For the } \\
\text { cost-effectiveness } \\
\text { estimate, the total } \\
\text { costs were divided } \\
\text { by the number of } \\
\text { responders. }\end{array}$ & $\begin{array}{l}\text { Steroid injection produced } \\
\text { significant treatment effects } \\
\text { and short-term improvement } \\
\text { in leg pain, straight leg raising, } \\
\text { disability, and in Nottingham } \\
\text { Health Profile and emotional } \\
\text { reactions. } \\
\text { In the subgroup analysis for } \\
\text { contained herniations, the } \\
\text { steroid injection produced } \\
\text { significant treatment effects. } \\
\text { By one-year, steroid seemed to } \\
\text { have prevented operations for } \\
\text { contained herniations, costing } \\
\$ 12,666 \text { less per respondant in } \\
\text { the steroid group }(\mathrm{P}<0.01) \text {. }\end{array}$ & $\begin{array}{l}\text { Positive short- } \\
\text { term relief and } \\
\text { negative long- } \\
\text { term relief. } \\
\text { For contained } \\
\text { herniations and } \\
\text { lesions at L3-L4- } \\
\text { L5, steroid treat- } \\
\text { ment also pre- } \\
\text { vented surgery } \\
\text { for contained } \\
\text { herniations. } \\
\text { However, steroid } \\
\text { was counter } \\
\text { effective for } \\
\text { extrusions. }\end{array}$ \\
\hline $\begin{array}{l}\text { Riew et al } \\
2006 / 2000 \\
(83,94) \\
\text { Prospective, } \\
\text { randomized, } \\
\text { controlled, } \\
\text { double-blind } \\
\text { study }\end{array}$ & $\begin{array}{l}55 \text { pts with lumbar disc } \\
\text { herniations or spinal } \\
\text { stenosis referred for surgical } \\
\text { evaluation. } \\
28 \text { pts. in experimental group } \\
\text { (bupivacaine and betametha- } \\
\text { sone) and } 27 \text { pts. in control } \\
\text { group (bupivacaine only). }\end{array}$ & $\begin{array}{l}\text { Experimental: trans- } \\
\text { foraminal nerve root } \\
\text { or epidural steroid } \\
\text { injection with } 1 \mathrm{~mL} \text { of } \\
0.25 \% \text { bupivacaine and } \\
6 \mathrm{mg} \text { of betametha- } \\
\text { sone Control: } 1 \mathrm{~mL} \text { of } \\
0.25 \% \text { bupivacaine. As } \\
\text { many as } 4 \text { injections } \\
\text { were given during the } \\
\text { follow-up. }\end{array}$ & $\begin{array}{l}\text { Initial outcomes } \\
\text { were evaluated at } \\
\text { one-year. Injection } \\
\text { was considered as a } \\
\text { failure if the patient } \\
\text { opted for operative } \\
\text { treatment. North } \\
\text { American Spine So- } \\
\text { ciety questionnaire } \\
\text { also used. }\end{array}$ & $\begin{array}{l}\text { Of the } 55 \text { randomized pts, } 29 \\
\text { avoided surgery at one-year. } \\
\text { Twenty-one of } 29 \text { were re- } \\
\text { evaluated. Seventeen of the } 21 \\
\text { pts. still had successful results } \\
\text { with no operative interven- } \\
\text { tion after } 5 \text { yrs. }\end{array}$ & $\begin{array}{l}\text { Positive short- } \\
\text { term and long- } \\
\text { term relief. }\end{array}$ \\
\hline $\begin{array}{l}\text { Vad et al } \\
2002(92) \\
\text { Prospective, } \\
\text { randomized } \\
\text { trial }\end{array}$ & $\begin{array}{l}\text { Patients with leg pain, with } \\
\text { documented herniated } \\
\text { nucleus pulposus or mani- } \\
\text { fested clinical signs such as } \\
\text { radicular pain with lumbar } \\
\text { radiculopathy. }\end{array}$ & $\begin{array}{l}\text { Experimental: beta- } \\
\text { methasone } 9 \mathrm{mg} \text {, and } \\
2 \% \text { preservative-free } \\
\text { Xylocaine }(1.5 \mathrm{~mL}) \text { per } \\
\text { level. } \\
\text { Control: trigger point } \\
\text { injections. }\end{array}$ & $\begin{array}{l}\text { Timing: } 3 \text { wks, } 6 \\
\text { wks, } 3 \text { mos., } 6 \text { mos., } \\
\text { and } 12 \text { mos. } \\
\text { Outcome measures: } \\
\text { Roland-Morris } \\
\text { score, visual numeric } \\
\text { score, finger-to-floor } \\
\text { distance, patient } \\
\text { satisfaction score. }\end{array}$ & $\begin{array}{l}\text { Group receiving transfo- } \\
\text { raminal epidural steroid } \\
\text { injections had } 84 \% \text { success } \\
\text { rate compared with } 48 \% \text { for } \\
\text { group receiving trigger point } \\
\text { injections. }\end{array}$ & $\begin{array}{l}\text { Positive short- } \\
\text { term and long- } \\
\text { term relief. }\end{array}$ \\
\hline $\begin{array}{l}\text { Jeong et al } \\
2007(45) \\
\text { Prospective } \\
\text { randomized } \\
\text { controlled } \\
\text { study }\end{array}$ & $\begin{array}{l}239 \text { consecutive pts were } \\
\text { randomly assigned to either } \\
\text { the ganglionic group or } \\
\text { pre-ganglionic group, with } 2 \\
\text { different types of injections } \\
\text { for pts with radicular pain } \\
\text { meeting the inclusion criteria } \\
\text { of the presence of lumbo- } \\
\text { sacral radiculopathy, clear } \\
\text { documentation of nerve root } \\
\text { compression with either sub- } \\
\text { articular or paracentral disc } \\
\text { herniation by using clinical } \\
\text { and cross sectional imaging } \\
\text { studies, following inclusion } \\
\text { criteria. Patients were divided } \\
\text { into } 2 \text { groups by duration of } \\
\text { pain with less than } 6 \text { months } \\
\text { and more than } 6 \text { months. } \\
46 \text { pts in the ganglionic group } \\
\text { and } 49 \text { pts in the pre-gan- } \\
\text { glionic group had pain for } \\
\text { longer than } 6 \text { months. }\end{array}$ & $\begin{array}{l}\text { Patients were random- } \\
\text { ized to receive either } \\
\text { the ganglionic or } \\
\text { the pre-ganglionic } \\
\text { transforaminal epidural } \\
\text { steroid injection at one } \\
\text { level. The pts in the } \\
\text { ganglionic group un- } \\
\text { derwent transforami- } \\
\text { nal epidural steroids } \\
\text { injection at the location } \\
\text { of the exiting nerve } \\
\text { root, whereas in the } \\
\text { pre-ganglionic group, } \\
\text { they underwent the } \\
\text { injection at the supra- } \\
\text { adjacent intervertebral } \\
\text { disc level and each } \\
\text { one received } 0.5 \text { mL of } \\
\text { bupivacaine hydro- } \\
\text { chloride and } 40 \text { mg of } \\
1 \text { mL of triamcinolone } \\
\text { acetonide. }\end{array}$ & $\begin{array}{l}\text { All pts under- } \\
\text { went outcomes at } \\
1 \text {-month and after } \\
6 \text { months, which } \\
\text { included visual } \\
\text { analog scale (VAS) } \\
\text { and a 4-grade scale } \\
\text { with regard to degree } \\
\text { of improvement, } \\
\text { excellent, good, } \\
\text { fair, or poor. They } \\
\text { considered 50\% or } \\
\text { greater in VAS along } \\
\text { with a self-reported } \\
\text { good to excellent } \\
\text { improvement as an } \\
\text { effective treatment. }\end{array}$ & $\begin{array}{l}\text { Short-term and mid-term fol- } \\
\text { low-up. Mid-term follow-up } \\
\text { was carried out after } 6 \text { mos., } \\
\text { only } 17 \text { pts were lost to mid- } \\
\text { term follow-up. Mean interval } \\
\text { of mid-term follow-up as } 373 \\
\text { days ranging from } 216 \text { to } 547 \\
\text { days. Results showed that the } \\
\text { pre-ganglionic group had a } \\
\text { better treatment effect than } \\
\text { did the ganglionic group, } \\
\text { however there were no signifi- } \\
\text { cant differences identified at } \\
\text { mid-term follow-up. }\end{array}$ & $\begin{array}{l}\text { Positive short- } \\
\text { term relief with } \\
\text { both techniques. } \\
\text { There was no } \\
\text { long-term fol- } \\
\text { low-up available, } \\
\text { even though it is } \\
\text { implied. }\end{array}$ \\
\hline
\end{tabular}


months but then equal pain and disability scores at 12 months. Karppinen et al (72) in their subgroup analysis of the randomized trial (90) showed significantly positive results for contained herniations at one-year.

Riew et al $(83,94)$ evaluated whether selective nerve root injections might help patients with lumbar radicular pain to avoid spine surgery. Fifty-five patients who were deemed surgical candidates were treated and randomized to receive either a selective nerve root injection of betamethasone $6 \mathrm{mg}$ with bupivacaine or a selective nerve root injection of bupivacaine alone. The patients were allowed up to 4 injections of the same study medicine during the evaluation. The patients were followed for between 13 and 28 months. There was no set follow-up evaluation at a short- or long-term point. At the end of the period, 18 of the 27 patients receiving only bupivacaine had chosen to undergo surgery. Of the $28 \mathrm{pa}-$ tients receiving the combination of betamethasone and bupivacaine, only 8 had undergone surgery. The difference was highly significant. In the follow-up study, Riew et al (83) showed positive long-term results with or without steroids.

Vad et al (92) studied the effect of transforaminal epidural betamethasone $9 \mathrm{mg}$ and lidocaine and compared it to a lumbar paraspinal muscle trigger point injection of saline. Forty-eight patients were included. Outcomes included pain score, patient satisfaction, and other measures of function. The patients were followed for an average of 1.4 years but no set shortor long-term follow-up evaluations were scheduled.
Patients improved in both groups but the transforaminal group did significantly better with a much lower pain score at the end and a larger percentage of patients ( $84 \%$ vs. $48 \%$ ) achieving a successful outcome in a shorter period of time than the trigger point group (6 weeks vs. 12 weeks).

\section{Effectiveness}

Of the 4 randomized trials evaluating lumbar transforaminal epidural steroid injections, all showed positive results for short-term relief $(45,72,83,90,92,94)$, 2 were positive for long-term relief $(83,92,94)$, the results of long-term relief were not available for one study $(45)$, whereas one was negative $(72,90)$.

Table 9 illustrates results of effectiveness of lumbar transforaminal epidural steroid injections.

\section{Level of Evidence}

The indicated evidence for lumbar transforaminal epidural steroid injections is Level II-1 for short-term relief and Level II-2 for long-term relief in managing chronic low back and lumbar nerve root pain based on USPSTF criteria.

\section{Recommendations}

Based on Guyatt et al's criteria (62), the recommendation for lumbar transforaminal epidurals is $1 \mathrm{C} /$ strong recommendation, moderate or low quality evidence, with a caveat that the recommendation may change when higher quality evidence becomes available.

Table 9. Results of randomized trials of effectiveness of lumbar transforaminal epidural injections.

\begin{tabular}{|c|c|c|c|c|c|c|c|c|}
\hline \multirow[b]{2}{*}{ Study } & \multirow[b]{2}{*}{$\begin{array}{c}\text { Study } \\
\text { Characteristics }\end{array}$} & \multirow[b]{2}{*}{$\begin{array}{l}\text { Methodological } \\
\text { Quality Scoring }\end{array}$} & \multirow[b]{2}{*}{ Participants } & \multicolumn{3}{|c|}{ Pain Relief } & \multicolumn{2}{|c|}{ Results } \\
\hline & & & & $3 \mathrm{mos}$ & $6 \mathrm{mos}$ & $12 \mathrm{mos}$ & $\begin{array}{c}\text { Short- } \\
\text { term } \\
\text { relief } \leq 6 \\
\text { months }\end{array}$ & $\begin{array}{c}\text { Long- } \\
\text { term } \\
\text { relief }>6 \\
\text { months }\end{array}$ \\
\hline $\begin{array}{l}\text { Karppinen et } \\
\text { al 2001/2001 } \\
(72,90)\end{array}$ & RA, DB & 81 & $\begin{array}{l}\mathrm{C}=80 \\
\mathrm{~T}=80\end{array}$ & $\mathrm{SICH}$ & NSI & NSI & $\mathrm{P}$ & $\mathrm{N}$ \\
\hline $\begin{array}{l}\text { Riew et al } \\
2006 / 2000 \\
(83,94)\end{array}$ & P, RA, DB & 68 & 55 & NA & NA & $\begin{array}{c}33 \% \text { vs. } 71 \% \\
\text { (avoided } \\
\text { surgery) }\end{array}$ & $\mathrm{P}$ & $\mathrm{P}$ \\
\hline $\begin{array}{l}\text { Jeong et al } 2007 \\
\text { (45) }\end{array}$ & RA, DB & 63 & 239 & $\begin{array}{c}\text { PG } 99 \text { of } 112 \\
\text { G } 90 \text { of } 127\end{array}$ & $\begin{array}{c}\text { PG } 64 \text { of } 106 \\
\text { G } 78 \text { of } 116\end{array}$ & $\mathrm{NA}$ & $\mathrm{P}$ & NA \\
\hline $\begin{array}{l}\text { Vad et al } 2002 \\
\text { (92) }\end{array}$ & RA & 58 & 48 & NA & NA & $48 \%$ vs. $84 \%$ & $\mathrm{P}$ & $\mathrm{P}$ \\
\hline
\end{tabular}

$P=$ prospective $; A=$ randomized $; \mathrm{DB}=$ double blind $; C=$ control $; \quad T=$ treatment $; \mathrm{PG}=$ pre-ganglionic; $\mathrm{G}=$ ganglionic; $\mathrm{SICH}=$ significant improvement in contained disc herniation; NSI = no significant improvement; vs. =versus; $N A=$ not available; $P=$ positive; $N=$ negative. 


\section{Complications}

The most common and worrisome complications of transforaminal epidural steroid injections in the lumbar spine, though rare, are related to neural trauma, vascular trauma, intravascular injection, and infection $(35,64,102-120)$.

Botwin et al (64) reported complications in 207 patients receiving 322 transforaminal lumbar epidural steroid injections. Complications included transient headaches in $3.1 \%$, increased back pain in $2.4 \%$, increased leg pain in $0.6 \%$, facial flushing in $1.2 \%$, vasovagal reaction in $0.3 \%$, increased blood sugar in $0.3 \%$, and hypertension in $0.3 \%$. The incidence of minor complications was $9.6 \%$ per injection with no major complications.

Furman et al (103) reported among the 761 transforaminal epidural steroid injections included in the study, the overall rate of intravascular injection was $11.2 \%$, with a higher rate of intravascular injections $(21.3 \%)$ at $\mathrm{S} 1$ transforaminal compared with those at the lumbar levels $(8.1 \%)$.

Manchikanti et al (35) reported intravenous placement of the needle in $22 \%$ of the procedures. Other complications included pain during the injection with back pain in $43 \%$ of the patients and leg pain in $22 \%$ of the patients. Postoperative complications were reported in $34 \%$ of the patients with soreness at the injection site in $18 \%$, increased pain in $5 \%$, muscle spasms in $4 \%$, swelling in $4 \%$, headache in $3 \%$, minor bleeding in $2 \%$, dizziness in $1 \%$, nausea and vomiting in $1 \%$, fever in $1 \%$, numbness in $1 \%$, and voiding difficulty in $1 \%$. Transforaminal injections have been reported with complications including spinal cord injury and infarction $(104,105)$, paraplegia (106), and intracord injection (105).

Huston et al (107) reported no major complications noted and $91 \%$ of the patients had no side effects during the injection. The most common side effect noted was increased pain at the injection site after the injection, which was seen in $17.1 \%$ of the lumbar patients.

Side effects related to the administration of steroids are generally attributed either to the chemistry or to the pharmacology of steroids (108). The major theoretical complications of corticosteroid administration include the suppression of pituitary adrenal axis, hypocorticism, Cushing's syndrome, osteoporosis, avascular necrosis of the bone, steroid myopathy, epidural lipomatosis, weight gain, fluid retention, and hyperglycemia (109117). Radiation exposure is also a potential problem with damage to eyes, skin, and gonads (118-120).

\section{Discussion}

This systematic review evaluating the effectiveness of lumbar transforaminal epidural injections in managing chronic radicular pain indicated Level II-1 or II-2 evidence, with a 1C/strong recommendation. Four randomized trials met the criteria for inclusion in this evaluation. The results of this systematic review are similar to the review by Abdi et al (32) and the reassessment of the American College of Occupational and Environmental Medicine (ACOEM) guidelines evidence by Manchikanti et al (28).

In 2008, Pearson et al (121) published their report assessing the effect of lumbar discectomy on patients with acute sciatica. The patients could be randomized into either the surgical group or the standard non-operative group. After randomization and surgery the patients were followed for up to 2 years. There was a 3 month follow-up assessment but no 6 month followup. They used a 6 point Likert-type scale to assess back pain "bothersomeness" as opposed to a standard numeric analog pain score. Looking at their data tables it is noted that the average back pain "bothersomeness" score for all groups is 3.9. Surgery reduced this score by $2.2(56.4 \%)$ for all surgical patients. The non-operative group's pain "bothersomeness" score decreased by 1.3 $(33 \%)$ in the same 3 months. After 3 months the scores in both groups essentially stabilized for the next 2 years. Their scores stayed roughly the same as at the 3 month mark, with a slight improvement in the non-operative group's score and a slight increase in the surgical group's score. The surgery group still had a better pain score at all time periods. In a second study, Mortimer and her colleagues (10) polled 790 patients with back pain that had sought care in any of several local clinics in Sweden. They did utilize a numerical pain score $(0-100)$ and a disability score different from any used in the 8 transforaminal groups. They polled the patients by a mailed questionnaire at 6 months, 2 years, and 5 years. Four hundred and fifty-nine patients completed the study. The baseline median pain score was 47 . At the 6 month mark the average pain score was calculated as 28.3 , based on an average score of 30 for the 202 men and a score of 27 for the 257 women. This is a change of 18.7 points or $39 \%$ from baseline. The disability improved dramatically at 6 months, from an average score of 27 to 7 , which is a $74 \%$ drop. In summary, disc surgery reduces the pain roughly the same amount as transforaminal lumbar epidural steroid injections as well as interlaminar and caudal epidurals at 3 months after treatment. The patients that received standard conservative therapy did about 
the same as patients that received transforaminal saline or local anesthetic but not as good as those that received an epidural steroid injection of any kind or surgery. In the Mortimer study, at 6 months the patients' pain had decreased, on its own, by about $39 \%$. This is less than the transforaminal steroid and transforaminal saline groups and about the same as the groups that received an interlaminar or caudal epidural steroid. Since Pearson et al's (121) surgery patients seemed to plateau at around 50\% reduction in pain score, we could assume that surgical patients would also be better than Mortimer's patients at 6 months.

The current systematic review shows that transforaminal epidural steroid injections, when appropriately performed, should result in significant improvement. These procedures can reduce the patient's pain by $64 \%$ to $81 \%$, disability by $60 \%$ to $63 \%$, and depression by $56 \%$. Considering the low risk and less expensive nature of the procedure, compared to surgical interventions, epidural injections with or without steroids seem to be cost effective (122-127).

With caudal and interlaminar epidurals, a common problem encountered is inaccurate needle placement, leading to inaccurate placement of the injectate. However, that is not an issue with transforaminal epidurals as it is required that transforaminal epidurals always be performed under fluoroscopy with contrast injection (128-132). Even then, there has been controversy with regards to the spread of the contrast with transforaminal epidural injections $(35,36,89,127,133-$ 135), showing a lack of ventral filling in some cases.

It appears that the underlying mechanism of action of epidurally administered steroid and local anesthetic is based on the belief that the achieved neural blockade alters or interrupts nociceptive input, the reflex mechanism of the afferent fibers, self-sustaining activity of the neurons, and the pattern of central neuronal activities $(109,136)$. Corticosteroids also have been shown to reduce inflammation by inhibiting either the synthesis or release of a number of pro-inflammatory mediators and by causing a reversible local anesthetic effect $(109,136-145)$. The emerging evidence also shows that the long-lasting effect may be obtained with local anesthetics with or without steroids $(88,146-164)$. In fact, in rat experiments of nerve root infiltration, Tachihara et al (145) illustrated that mechanical allodynia was prevented by local anesthetic with or without steroid, even though no additional benefit from using corticosteroid was identified. Thus, it is suggested that corticosteroids may be unnecessary for nerve root blocks. This concept has been reinforced by numerous randomized and observational studies $(36,123-126,156,158,161-168)$.

The results of this systematic review may be applied in interventional pain management practices utilizing appropriate evaluations. Further, these results are also generalizable.

The limitations of this study include that we were able to find only 4 appropriately performed studies which met inclusion criteria and were clinically relevant. Further, methodologic criteria has been highly variable along with sample sizes. The studies were heterogenous.

The results of this systematic review have significant implications for clinical practice. Transforaminal epidural injections show a significant reduction of pain scores in patients with lumbar radiculitis when compared to doing nothing, conservative management without injection therapy, and probably lumbar interlaminar epidural injections (53). However, the differences between transforaminal and caudal epidural are not significantly different based on the recent systematic review of caudal epidural injections (51).

The future implications for research should include a clear case definition with consistent inclusion and exclusion criteria, clear outcome measures, appropriate design, and reporting of randomized trials $(58,59,169-171)$.

\section{Conclusion}

The results of this systematic evaluation of lumbar transforaminal epidural injections showed that they have significant effect in relieving chronic pain of lumbar disc herniation and radiculitis with indicated evidence levels of Level II- 1 to II-2 with a $1 \mathrm{C} /$ strong recommendation. However, evidence must be examined on a regular basis and the data needs to be updated if further evidence becomes available.

\section{Acknowledgments}

The authors wish to thank the editorial board of Pain Physician, for review and criticism in improving the manuscript; Margaret Chappell, librarian at the Kettering Medical Center Medical Library in Kettering, Ohio, for her assistance in finding many reference articles for this systematic review; Sekar Edem for assistance in search of literature; and Tonie M. Hatton and Diane E. Neihoff, transcriptionists (Pain Management Center of Paducah), for their assistance in preparation of this manuscript. 


\section{References}

1. Blyth FM, March LM, Brnabic AJ, Jorm LR, Williamson M, Cousins MJ. Chronic pain in Australia: A prevalence study. Pain 2001; 89:127-134.

2. Verhaak PF, Kerssens JJ, Dekker J, Sorbi MJ, Bensing JM. Prevalence of chronic benign pain disorder among adults: A review of the literature. Pain 1998; 77:231-239.

3. Elliott AM, Smith BH, Hannaford PC, Smith WC, Chambers WA. The course of chronic pain in the community: Results of a 4-year follow-up study. Pain 2002; 99:299-307.

4. Lawrence RC, Helmick CG, Arnett FC, Deyo RA, Felson DT, Giannini EH, Heyse SP, Hirsch R, Hochberg MC, Hunder GG, Liang MH, Pillemer SR, Steen VD, Wolfe F. Estimates of the prevalence of arthritis and selected musculoskeletal disorders in the United States. Arthritis Rheum 1998; 41:778-799.

5. Cassidy JD, Carroll LJ, Côté P. The Saskatchewan health and back pain survey. The prevalence of low back pain and related disability in Saskatchewan adults. Spine 1998; 23:1860-1866.

6. Guo HR, Tanaka S, Halperin WE, Cameron LL. Back pain prevalence in US industry and estimates of lost workdays. Am J Public Health 1999; 89:1029-1035.

7. Linton SJ, Hellsing AL, Halldén K. A population-based study of spinal pain among 35-45-year-old individuals. Prevalence, sick leave, and health care use. Spine 1998; 23:1457-1463.

8. Bressler HB, Keyes WJ, Rochon PA, Badley $E$. The prevalence of low back pain in the elderly. A systematic review of the literature. Spine 1999; 24:1813-1819.

9. Cecchi F, Debolini P, Lova RM, Macchi C, Bandinelli S, Bartali B, Lauretani F, Benvenuti E, Hicks G, Ferrucci L. Epidemiology of back pain in a representative cohort of Italian persons 65 years of age and older: The InCHIANTI study. Spine 2006; 31:1149-1155.

10. Mortimer M, Pernold G, Wiktorin C. Low back pain in a general population. Natural course and influence of physical exercise - a 5-year follow-up of the Musculoskeletal Intervention Center-Norrtälje Study. Spine 2006; 31:3045-3051.

11. Kuslich SD, Ulstrom CL, Michael CJ. The tissue origin of low back pain and sciatica: A report of pain response to tissue stimulation during operation on the lumbar spine using local anesthesia. Orthop Clin North Am 1991; 22:181-187.

12. Mixter WJ, Barr JS. Rupture of the intervertebral disc with involvement of the spinal canal. N Eng J Med 1934; 211:210215.

13. Wheeler AH, Murrey DB. Chronic lumbar spine and radicular pain: Pathophysiology and treatment. Curr Pain Headache Rep 2002; 6:97-105.

14. Mixter WJ, Ayers JB. Herniation or rupture of the intervertebral disc into the spinal canal. N Engl J Med 1935; 213:385-395.

15. Manchikanti L, Singh V, Pampati V, Damron K, Barnhill R, Beyer C, Cash K. Evaluation of the relative contributions of various structures in chronic low back pain. Pain Physician 2001; 4:308-316.

16. Hadjipavlou AG, Tzermiadianos MN, Bogduk N, Zindrick MR. The pathophysiology of disc degeneration: A critical review. J Bone Joint Surg Br 2008; 90:1261-1270.

17. McCarron RF, Wimpee MW, Hudkins PG, Laros GS. The inflammatory effects of nucleus pulposus: A possible element in the pathogenesis of low back pain. Spine 1987; 12:760-764.

18. Olmarker K, Blomquist J, Stromberg J, Nannmark U, Thomsen P, Rydevik B. Inflammatogenic properties of nucleus pulposus. Spine 1995; 20:665-669.

19. Norimoto M, Ohtori S, Yamashita M, Inoue G, Yamauchi K, Koshi T, Suzuki M, Orita S, Eguchi Y, Sugiura A, Ochiai N, Takaso M, Takahashi K. Direct application of the TNF-alpha inhibitor, etanercept, does not affect CGRP expression and phenotypic change of DRG neurons following application of nucleus pulposus onto injured sciatic nerves in rats. Spine 2008; 33:2403-2408.

20. Uchida K, Baba H, Maezawa Y, Kubota $C$. Progressive changes in neurofilament proteins and growth-associated protein-43 immunoreactivities at the site of cervical spinal cord compression in spinal hyperostotic mice. Spine 2002; 27:480-486.

21. Yamashita M, Ohtori S, Koshi T, Inoue G Yamauchi K, Suzuki M, Takahashi K. Tumor necrosis factor-alpha in the nucleus pulposus mediates radicular pain, but not increase of inflammatory peptide, associated with nerve damage in mice. Spine 2008; 33:1836-1842.
22. Boswell MV, Trescot AM, Datta S, Schultz DM, Hansen HC, Abdi S, Sehgal N, Shah RV, Singh V, Benyamin RM, Patel VB, Buenaventura RM, Colson JD, Cordner HJ, Epter RS, Jasper JF, Dunbar EE, Atluri SL, Bowman RC, Deer TR, Swicegood JR, Staats PS, Smith HS, Burton AW, Kloth DS, Giordano J, Manchikanti L. Interventional techniques: Evidencebased practice guidelines in the management of chronic spinal pain. Pain Physician 2007; 10:7-111.

23. Manchikanti L, Hirsch JA. Issues in Health Care: Interventional pain management at the crossroads. Health Policy Update. Pain Physician 2007; 10:261-284.

24. Manchikanti L, Giordano J. Physician payment 2008 for interventionalists: Current state of health care policy. Pain Physician 2007; 10:607-626.

25. Manchikanti L, Boswell MV. Interventional techniques in ambulatory surgical centers: A look at the new payment system. Pain Physician 2007; 10:627650.

26. Specialty Utilization data files from Centers for Medicare and Medicaid Services. Medicare: www.cms.hhs.gov/

27. Staal JB, de Bie R, de Vet HC, Hildebrandt J, Nelemans P. Injection therapy for subacute and chronic low-back pain. Cochrane Database Syst Rev 2008; 3:CDo01824.

28. Manchikanti L, Singh V, Derby R, Schultz DM, Benyamin RM, Prager JP, Hirsch JA. Reassessment of evidence synthesis of occupational medicine practice guidelines for interventional pain management. Pain Physician 2008; 11:393482.

29. Armon C, Argoff CE, Samuels J, Backonja MM; Therapeutics and Technology Assessment Subcommittee of the American Academy of Neurology. Assessment: Use of epidural steroid injections to treat radicular lumbosacral pain: Report of the Therapeutics and Technology Assessment Subcommittee of the American Academy of Neurology. Neurology 2007; 68:723-729.

30. Friedly J, Chan L, Deyo R. Increases in lumbosacral injections in the Medicare population: 1994 to 2001. Spine 2007; 32:1754-1760.

31. Friedly J, Nishio I, Bishop MJ, Maynard C. The relationship between repeated 
epidural steroid injections and subsequent opioid use and lumbar surgery. Arch Phys Med Rehabil 2008; 89:10111015.

32. Abdi S, Datta S, Trescot AM, Schultz DM, Adlaka R, Atluri SL, Smith HS, Manchikanti L. Epidural steroids in the management of chronic spinal pain: A systematic review. Pain Physician 2007; 10:185-212.

33. Datta S, Everett CR, Trescot AM, Schultz DM, Adlaka R, Abdi S, Atluri SL, Smith HS, Shah RV. An updated systematic review of diagnostic utility of selective nerve root blocks. Pain Physician 2007; 10:113-128.

34. Bogduk N, Christophidis N, Cherry D. Epidural use of steroids in the management of back pain. Report of working party on epidural use of steroids in the management of back pain. National Health and Medical Research Council. Canberra, Commonwealth of Australia, 1994; pp 1-76.

35. Manchikanti L, Cash KA, Pampati V, Damron KS, McManus CD. Evaluation of lumbar transforaminal epidural injections with needle placement and contrast flow patterns: A prospective, descriptive report. Pain Physician 2004; 7:217-223.

36. Manchikanti L. Transforaminal lumbar epidural steroid injections. Pain Physician 2000; 3:374-398.

37. Manchikanti L, Pakanati RR, Pampati V. Comparison of three routes of epidural steroid injections in low back pain. Pain Digest 1999; 9:277-285.

38. DePalma MJ, Bhargava A, Slipman CW. A critical appraisal of the evidence for selective nerve root injection in the treatment of lumbosacral radiculopathy. Arch Phys Med Rehabil 2005; 86:14771483.

39. Airaksinen O, Brox JI, Cedraschi C, Hildebrandt J, Klaber-Moffett J, Kovacs F, Mannion AF, Reis S, Staal JB, Ursin H, Zanoli G. Chapter 4: European guidelines for the management of chronic nonspecific low back pain. Eur Spine J 2006; 15:S192-S300.

40. American College of Occupational and Environmental Medicine. Low Back Disorders Chapter. In: Occupational Medicine Practice Guidelines: Evaluation and Management of Common Health Problems and Functional Recovery of Workers, Second Edition. American College of Occupational and Environmental Medicine, Elk Grove Village, 2007.
41. American College of Occupational and Environmental Medicine. Chronic Pain Chapter (revised 2008). In: Occupational Medicine Practice Guidelines: Evaluation and Management of Common Health Problems and Functional Recovery of Workers, Second Edition. American College of Occupational and Environmental Medicine, Elk Grove Village, Epublished August 14, 2008.

42. Manchikanti L, Singh V, Derby R, Helm S, Trescot AM, Staats PS, Prager JP, Hirsch JA. Review of occupational medicine practice guidelines for interventional pain management and poten tial implications. Pain Physician 2008; 11:271-289.

43. Gallucci M, Limbucci N, Zugaro L, Barile A, Stavroulis E, Ricci A, Galzio R, Masciocchi C. Sciatica: Treatment with intradiscal and intraforaminal injections of steroid and oxygen-ozone versus steroid only. Radiology 2007; 242:907913.

44. Bonetti M, Fontana A, Cotticelli B, Volta GD, Guindani M, Leonardi M. Intraforaminal $\mathrm{O}(2)-\mathrm{O}(3)$ versus periradicular steroidal infiltrations in lower back pain: Randomized controlled study. AJNR Am J Neuroradiol 2005; 26:9961000.

45. Jeong HS, Lee JW, Kim SH, Myung JS, Kim JH, Kang HS. Effectiveness of transforaminal epidural steroid injection by using a preganglionic approach: A prospective randomized controlled study. Radiology 2007; 245:584-590.

46. Johnson BA. Therapeutic periradicular injections: It's a gas. AJNR Am J Neuroradiol 2005; 26:988-989.

47. Koes BW, Scholten RJ, Mens JMA, Bouter LM. Efficacy of epidural steroid injections for low-back pain and sciatica: A systematic review of randomized clinical trials. Pain 1995; 63:279-288.

48. West S, King V, Carey TS, Lohr KN, McKoy N, Sutton SF, Lux L. Systems to Rate the Strength of Scientific Evidence, Evidence Report, Technology Assessment No. 47. AHRQ Publication No. 02E016. Rockville, MD: Agency for Healthcare Research and Quality, 2002. www. thecre.com/pdf/ahrq-system-strength. pdf

49. Atluri S, Datta S, Falco FJ, Lee M. Systematic review of diagnostic utility and therapeutic effectiveness of thoracic facet joint interventions. Pain Physician 2008; 11:611-629.

50. Helm S, Hayek S, Benyamin R, Manchikanti L. Systematic review of ef- fectiveness of thermal annular procedures in treating discogenic low back pain. Pain Physician 2009; 12:207232.

51. Conn A, Buenaventura R, Datta S, Abdi $S$, Diwan S. Systematic review of caudal epidurals injections in the management of chronic low back pain. Pain Physician 2009; 12:109-135.

52. Benyamin R., Singh V, Parr AT, Conn A, Diwan S, Abdi S. Systematic review of the effectiveness of cervical epidurals in the management of chronic neck pain. Pain Physician 2009; 12:137-157.

53. Parr AT, Diwan S, Abdi S. Lumbar interlaminar epidural injections in managing chronic low back and lower extremity pain: A systematic review. Pain Physician 2009; 12:163-188.

54. van Tulder $M$, Furlan $A$, Bombardier C, Bouter L, Editorial Board of the Cochrane Collaboration Back Review Group. Updated method guidelines for systematic reviews in the Cochrane Collaboration Back Review Group. Spine 2003; 28:1290-1299.

55. Salaffi F, Stancati A, Silvestri CA, Ciapetti A, Grassi W. Minimal clinically important changes in chronic musculoskeletal pain intensity measured on a numerical rating scale. Eur J Pain 2004; 8:283-291.

56. Bombardier C. Outcome assessments in the evaluation of treatment of spinal disorders: Summary and general recommendations. Spine 2000; 25:31003103.

57. Manchikanti L. Evidence-based medicine, systematic reviews, and guidelines in interventional pain management: Part 1: Introduction and general considerations. Pain Physician 2008; 11:161-186.

58. Manchikanti L, Hirsch JA, Smith HS. Evidence-based medicine, systematic reviews, and guidelines in interventional pain management: Part 2: Randomized controlled trials. Pain Physician 2008; 11:717-773.

59. Manchikanti L, Singh V, Helm II S, Hirsch JA. Evidence-based medicine, systematic reviews, and guidelines in interventional pain management: Part 3: Systematic reviews and meta-analysis of randomized trials. Pain Physician 2009; 12:35-72.

6o. Manchikanti L, Smith HS, Hirsch JA. Evidence-based medicine, systematic reviews, and guidelines in interventional pain management: Part 4: Observational studies. Pain Physician 2009;12:73- 
108.

61. Berg AO, Allan JD. Introducing the third U.S. Preventive Services Task Force. Am J Prev Med 2001; 20:21-35.

62. Guyatt G, Gutterman D, Baumann MH, Addrizzo-Harris D, Hylek EM, Phillips B, Raskob G, Lewis SZ, Schünemann $\mathrm{H}$. Grading strength of recommendations and quality of evidence in clinical guidelines. Report from an American College of Chest Physicians Task Force. Chest 2006; 129:174-181.

63. Blankenbaker DG, De Smet AA, Stanczak JD, Fine JP. Lumbar radiculopathy: Treatment with selective lumbar nerve blocks - comparison of effectiveness of triamcinolone and betamethasone injectable suspensions. Radiology 2005; 237:738-741.

64. Botwin KP, Gruber RD, Bouchlas CG, Torres-Ramos FM, Freeman TL, Slaten WK. Complications of fluoroscopically guided transforaminal lumbar epidural injections. Arch Phys Med Rehabil 2000; 81:1045-1050.

65. Botwin KP, Gruber RD, Bouchlas CG, Torres-Ramos FM, Sanelli JT, Freeman ED, Slaten WK, Rao S. Fluoroscopically guided lumbar transformational epidural steroid injections in degenerative lumbar stenosis: An outcome study. Am J Phys Med Rehabil 2002; 81:898905.

66. Choi SJ, Song JS, Kim C, Shin MJ, Ryu DS, Ahn JH, Jung SM, Park MS. The use of magnetic resonance imaging to predict the clinical outcome of non-surgical treatment for lumbar intervertebral disc herniation. Korean J Radiol 2007; 8:156-163.

67. Cooper G, Lutz GE, Boachie-Adjei O, Lin J. Effectiveness of transforaminal epidural steroid injections in patients with degenerative lumbar scoliotic stenosis and radiculopathy. Pain Physician 2004; 7:311-317.

68. Devulder J. Transforaminal nerve root sleeve injection with corticosteroids, hyaluronidase, and local anesthetic in the failed back surgery syndrome. $J$ Spinal Disord 1998; 11:151-154.

69. Faraj AA, Mulholland RC. The value of nerve root infiltration for leg pain when used with a nerve stimulator. Eur Spine J 2006; 15:1495-1499.

70. Grönemeyer D, Seibel R, Schindler O, Schattauer K, Lange S, Schmidt A. Microinvasive, CT-controlled periradicular therapy in treatment of chronic intervertebral disk-induced functional disorders. Wien Med Wochenschr 1995
145:129-139.

71. Karaemino ullari O, Sahin O, Boyvat F, Akgün RC, Gürün U, Demirörs H, Tuncay IC, Tando an RN. Transforaminal epidural steroid injection under computed tomography guidance in relieving lumbosacral radicular pain. Acta Orthop Traumatol Turc 2005; 39:416-420.

72. Karppinen J, Ohinmaa A, Malmivaara A, Kurunlahti M, Kyllönen E, Pienimäki T, Nieminen P, Tervonen O, Vanharanta $\mathrm{H}$. Cost effectiveness of periradicular infiltration for sciatica: Subgroup analysis of a randomized controlled trial. Spine 2001; 26:2587-2595.

73. Kolsi I, Delecrin J, Berthelot JM, Thomas L, Prost A, Maugars Y. Efficacy of nerve root versus interspinous injections of glucocorticoids in the treatment of disk-related sciatica. A pilot, prospective, randomized, double-blind study. Joint Bone Spine 2000; 67:113-118.

74. Kraemer J, Ludwig J, Bickert U, Owczarek V, Traupe M. Lumbar epidural perineural injection: A new technique. Eur Spine 1997; 6:357-361.

75. Lee IS, Kim SH, Lee JW, Hong SH, Choi JY, Kang HS, Song JW, Kwon AK. Comparison of the temporary diagnostic relief of transforaminal epidural steroid injection approaches: Conventional versus posterolateral technique. AJNR Am J Neuroradiol 2007; 28:204-208.

76. Lee JW, Kim SH, Choi JY, Yeom JS, Kim KJ, Chung SK, Kim HJ, Kim C, Kwack KS, Kwon JW, Moon SG, Jun WS, Kang HS. Transforaminal epidural steroid injection for lumbosacral radiculopathy: Preganglionic versus conventional approach. Korean / Radiol 2006; 7:139144.

77. Lee JW, Kim SH, Lee IS, Choi JA, Choi JY, Hong SH, Kang HS. Therapeutic effect and outcome predictors of sciatica treated using transforaminal epidural steroid injection. AJR Am J Roentgenol 2006; 187:1427-1431.

78. Lutz GE, Vad VB, Wisneski RJ. Fluoroscopic transforaminal lumbar epidural steroids: An outcome study. Arch Phys Med Rehabil 1998; 79:1362-1366.

79. Lutze M, Stendel R, Vesper J, Brock $M$. Periradicular therapy in lumbar radicular syndromes: Methodology and results. Acta Neurochir (Wien) 1997; 139:719-724.

80. Michel JL, Lemaire S, Bourbon H, Reynier C, Lhoste A, Soubrier S, Dubost JJ, Ristori JM. Fluoroscopy guided $\mathrm{L}_{5}-\mathrm{S}_{1}$ transforaminal injection as a treatement for s1 radiculopathy. / Radiol
2004; 85:1937-1941.

81. Narozny M, Zanetti M, Boos N. Therapeutic efficacy of selective nerve root blocks in the treatment of lumbar radicular leg pain. Swiss Med Wkly 2001; 131:75-80.

82. Pfirrmann CW, Oberholzer PA, Zanetti M, Boos N, Trudell DJ, Resnick D, Hodler J. Selective nerve root blocks for the treatment of sciatica: Evaluation of injection site and effectiveness - a study with patients and cadavers. Radiology 2001; 221:704-711.

83. Riew KD, Park JB, Cho YS, Gilula L, Patel A, Lenke LG, Bridwell KH. Nerve root blocks in the treatment of lumbar radicular pain. A minimum five-year follow-up. J Bone Joint Surg Am 2006; 88:1722-1725.

84. Schmid G, Schmitz A, Borchardt D, Ewen K, von Rothenburg T, Koester O, Jergas M. Effective dose of CT- and fluoroscopy-guided perineural/epidural injections of the lumbar spine: A comparative study. Cardiovasc Intervent Radiol 2006; 29:84-91.

85. Viton JM, Rubino T, Peretti-Viton P, Bouvenot $G$, Delarque A. Short-term evaluation of periradicular corticosteroid injections in the treatment of lumbar radiculopathy associated with disc disease. Rev Rhum Engl Ed 1998; 65:195200.

86. Weiner BK, Fraser RD. Foraminal injection for lateral lumbar disc herniation. J Bone Joint Surg Br 1997; 79:804-807.

87. Yamagami H, Hashizume K, Sha K, Furuya $\mathrm{H}$, Okuda T. Evaluation of selective lumbar radiculography and radicular block. Masui 1994; 43:253-257.

88. Yang SC, Fu TS, Lai PL, Niu CC, Chen LH, Chen WJ. Transforaminal epidural steroid injection for discectomy candidates: An outcome study with a minimum of two-year follow-up. Chang Gung Med I 2006; 29:93-99.

89. Ackerman WE 3rd, Ahmad M. The efficacy of lumbar epidural steroid injections in patients with lumbar disc herniations. Anesth Analg 2007; 104:12171222.

90. Karppinen J, Malmivaara A, Kurunlahti M, Kyllönen E, Pienimäki T, Nieminen P, Ohinmaa A, Tervonen O, Vanharanta $\mathrm{H}$. Periradicular infiltration for sciatica: A randomized controlled trial. Spine 2001; 26:1059-1067.

91. Berger O, Dousset V, Delmer O, Pointillart V, Vital JM, Caillé JM. Evaluation of the efficacy of foraminal infusions 
of corticosteroids guided by computed tomography in the treatment of radicular pain by foraminal injection. J Radiol 1999; 80:917-925.

92. Vad VB, Bhat AL, Lutz GE, Cammisa F. Transforaminal epidural steroid injections in lumbosacral radiculopathy: A prospective randomized study. Spine 2002; 27:11-16.

93. Ng L, Chaudhary N, Sell P. The efficacy of corticosteroids in periradicular infiltration for chronic radicular pain: A randomized, double-blind, controlled trial. Spine 2005; 30:857-862.

94. Riew KD, Yin Y, Gilula L, Bridwell KH, Lenke LG, Lauryssen C, Goette K. The effect of nerve-root injections on the need for operative treatment of lumbar radicular pain. A prospective, randomized, controlled, double-blind study. J Bone Joint Surg Am 2000; 82-A:15891593.

95. Thomas E, Cyteval C, Abiad L, Picot MC, Taourel P, Blotman F. Efficacy of transforaminal versus interspinous corticosteroid injection in discal radiculalgia - a prospective, randomised, double-blind study. Clin Rheumatol 2003; 22:299-304.

96. Tajima T, Furukawa K, Kuramochi E. Selective lumbosacral radiculography and block. Spine 1980; 5:68-77.

97. Steindler A, Luck J. Differential diagnosis of pain low in the back. JAMA 1938; 110:106-113.

98. Macnab I. Negative disc exploration. An analysis of the causes of nerve-root involvement in sixty-eight patients. Bone Joint Surg Am 1971; 53:891-903.

99. Schutz H, Lougheed WM, Wortzman G, Awerbuck BG. Intervertebral nerve-root in the investigation of chronic lumbar disc disease. Can J Surg 1973; 16:217221.

100. Krempen JF, Smith BS. Nerve-root injection: A method for evaluating the etiology of sciatica. J Bone Joint Surg Am 1974; 56:1435-1444.

101. Butterman GR. Treatment of lumbar disc herniation: Epidural steroid injection compared with discectomy. A prospective, randomized study. J Bone Joint Surg Am 2004; 86-A:670-679.

102. Everett CR, Baskin MN, Novoseletsky D, Speach D, Patel R. Flushing as a side effect following lumbar transforaminal epidural steroid injection. Pain Physician 2004; 7:427-429.

103. Furman MB, O’Brien EM, Zgleszewski TM. Incidence of intravascular penetra- tion in transforaminal lumbosacral epidural steroid injections. Spine 2000; 25:2628-2632.

104. Glaser SE, Falco F. Paraplegia following a thoracolumbar transforaminal epidural steroid injection. Pain Physician 2005; 8:309-314.

105. Bromage RP, Benumof JL. Paraplegia following intracord injection during attempted epidural anesthesia under general anesthesia. Reg Anesth Pain Med 1998; 23:104-107.

106. Houten JK, Errico TJ. Paraplegia after lumbosacral nerve root block: Report of three cases. Spine J 2002; 2:70-75.

107. Huston CW, Slipman CW, Garvin C. Complications and side effects of cervical and lumbosacral selective nerve root injections. Arch Phys Med Rehabil 2005; 86:277-283.

108. Manchikanti L. Pharmacology of neuraxial steroids. In: Manchikanti L, Singh $\mathrm{V}$ (eds). Interventional Techniques in Chronic Spinal Pain. ASIPP Publishing, Paducah, KY, 2007, pp 167-184.

109. Manchikanti L. Role of neuraxial steroids in interventional pain management. Pain Physician 2002; 5:182-199.

110. Derby R, Bogduk N, Anat D, Kine G. Precision percutaneous blocking procedures for localizing spinal pain. Part 2. The lumbar neuraxial compartment. Pain Digest 1993; 3:175-188.

111. Hughes JM, Hichens M, Booze GW, Thorner MO. Cushing's syndromes from therapeutic use of intramuscular dexamethasone acetate. Arch Intern Med 1986; 146:1848-1849.

112. Buckley LM, Marquez M, Feezor R, Ruffin DM, Benson LL. Prevention of corticosteroid-induced osteoporosis: Results of a patients survey. Arthritis Rheum 1999; 42:1736-1739.

113. Boonen S, Van Distel G, Westhovens R, Dequeker J. Steroid myopathy induced by epidural triamcinolone injection. Brit J Rheumatol 1995; 34:385.

114. Sandberg DI, Lavyne MH. Symptomatic spinal epidural lipomatosis after local epidural corticosteroid injections: Case report. Neurosurgery 1999; 45:162165.

115. Manchikanti L, Pampati VS, Beyer C, Damron KS, Cash KA, Moss TL. The effect of neuraxial steroids on weight and bone mass density: A prospective evaluation. Pain Physician 2000; 3:357366.

116. Clinkscales A, Cleary JD. Steroid-induced avascular necrosis. Ann Phar- macother 2002; 36:1105.

117. Mikhail GR, Sweet LC, Mellinger RC. Parenteral long-acting corticosteroid effect on hypothalamic pituitary adrenal function. Ann Allergy 1973; 31:337343.

118. Manchikanti L, Cash KA, Moss TL, Pampati $V$. Effectiveness of protective measures in reducing risk of radiation exposure in interventional pain management: A prospective evaluation. Pain Physician 2003; 6:301-305.

119. Manchikanti L, Cash KA, Moss TL, Rivera JJ, Pampati V. Risk of whole body radiation exposure and protective measures in fluoroscopically guided interventional techniques: $A$ prospective evaluation. BMC Anesthesiol 2003; 3:2.

120. Manchikanti L, Cash KA, Moss TL, Pampati V. Radiation exposure to the physician in interventional pain management. Pain Physician 2002; 5:385-393.

121. Pearson AM, Blood EA, Frymoyer JW, Herkowitz H, Abdu WA, Woodward R, Longley M, Emery SE, Lurie JD, Tosteson TD, Weinstein JN. SPORT lumbar intervertebral disk herniation and back pain: Does treatment, location, or morphology matter? Spine 2008; 33:428435.

122. Huntoon MC, Burgher AH. Back to the future: The end of the steroid century. Pain Physician 2008; 11:713-716.

123. Manchikanti L, Cash KA, McManus CD, Pampati V, Smith HS. Preliminary results of randomized, equivalence trial of fluoroscopic caudal epidural injections in managing chronic low back pain: Part 1. Discogenic pain without disc herniation or radiculitis. Pain Physician 2008; 11:785-800.

124. Manchikanti L, Singh V, Cash KA, Pampati V, Damron KS, Boswell MV. Preliminary results of randomized, equivalence trial of fluoroscopic caudal epidural injections in managing chronic low back pain: Part 2. Disc herniation and radiculitis. Pain Physician 2008; 11:801-815.

125. Manchikanti L, Singh V, Cash KA, Pampati V, Datta S. Preliminary results of randomized, equivalence trial of fluoroscopic caudal epidural injections in managing chronic low back pain: Part 3. Post surgery syndrome. Pain Physician 2008; 11:817-831.

126. Manchikanti L, Cash KA, McManus CD, Pampati V, Abdi S. Preliminary results of randomized, equivalence trial of flu- 
oroscopic caudal epidural injections in managing chronic low back pain: Part 4. Spinal stenosis. Pain Physician 2008; 11:833-848.

127. Manchikanti L, Schultz DM, Racz GB. Lumbar transforaminal epidural injections. In Manchikanti L, Singh V (eds). Interventional Techniques in Chronic Spinal Pain, ASIPP Publishing, Paducah, KY, 2007, pp 423-454.

128. Fredman B, Nun MB, Zohar E, Iraqi G, Shapiro M, Gepstein R, Jedeikin R. Epidural steroids for treating "failed back surgery syndrome": Is fluoroscopy really necessary? Anesth Analg 1999; 88:367-372.

129. Mehta M, Salmon N. Extradural block. Confirmation of the injection site by $\mathrm{X}$-ray monitoring. Anaesthesia 1985; 40:1009-1012.

130. Bartynski WS, Grahovac SZ, Rothfus WE. Incorrect needle position during lumbar epidural steroid administration: Inaccuracy of loss of air pressure resistance and requirement of fluoroscopy and epidurography during needle insertion. Am / Neuroradiol 2005; 26:502-505.

131. Botwin KP, Natalicchio J, Hanna A. Fluoroscopic guided lumbar interlaminar epidural injections: A prospective evaluation of epidurography contrast patterns and anatomical review of the epidural space. Pain Physician 2004; 7:77-80.

132. Weil L, Frauwirth NH, Amirdelfan K, Grant D, Rosenberg JA. Fluoroscopic analysis of lumbar epidural contrast spread after lumbar interlaminar injection. Arch Phys Med Rehabil 2008; 89:413-416.

133. Everett CR, Shah R, Sehgal N, McKenzie-Brown AM. A systematic review of diagnostic utility of selective nerve root blocks. Pain Physician 2005; 8:225233.

134. Furman MB, Lee TS, Mehta A, Simon JI, Cano WG. Contrast flow selectivity during lumbosacral epidural steroid injection. Pain Physician 2008; 11:855-861.

135. Young IA, Hyman GS, Packia-Raj LN, Cole AJ. The use of lumbar epidural/ transforaminal steroids for managing spinal disease. J Am Acad Orthop Surg 2007; 15:228-238.

136. Dietrich CL, Smith CE. Epidural granuloma and intracranial hypotension resulting from cervical epidural steroid injection. Anesthesiology 2004; 100:445447.
137. Pasqualucci A, Varrassi G, Braschi A, Peduto VA, Brunelli A, Marinangeli $F$, Gori F, Colò F, Paladini A, Mojoli F. Epidural local anesthetic plus corticosteroid for the treatment of cervical brachial radicular pain: Single injection versus continuous infusion. Clin J Pain 2007; 23:551-557.

138. Byrod G, Otani K, Brisby H, Rydevik B, Olmarker K. Methylprednisolone reduces the early vascular permeability increase in spinal nerve roots induced by epidural nucleus pulposus application. J Orthop Res 2000; 18:983-987.

139. Flower RJ, Blackwell GJ. Anti-inflammatory steroid induced biosynthesis of a phospholipase A2 inhibitor which prevents prostaglandin generation. Nature 1979; 278:456-459.

140. Lundin A, Magnuson A, Axelsson K, Nilsson O, Samuelsson L. Corticosteroids preoperatively diminishes damage to the C-fibers in microscopic lumbar disc surgery. Spine 2005; 30:23622367.

141. Hua SY, Chen YZ. Membrane receptormediated electrophysiological effects of glucocorticoid on mammalian neurons. Endocrinology 1989; 124:687691.

142. Hayashi N, Weinstein JN, Meller ST, Lee HM, Spratt KF, Gebhart GF. The effect of epidural injection of betamethasone or bupivacaine in a rat model of lumbar radiculopathy. Spine 1998; 23:877885.

143. Lee HM, Weinstein JN, Meller ST, Hayashi N, Spratt KF, Gebhart GF. The role of steroids and their effects on phospholipase A2: An animal model of radiculopathy. Spine 1998; 23:11911196.

144. Minamide A, Tamaki T, Hashizume H, Yoshida M, Kawakami M, Hayashi N. Effects of steroids and lipopolysaccharide on spontaneous resorption of herniated intervertebral discs: An experimental study in the rabbit. Spine 1998 ; 23:870-876.

145. Tachihara H, Sekiguchi M, Kikuchi S, Konno S. Do corticosteroids produce additional benefit in nerve root infiltration for lumbar disc herniation. Spine 2008; 33:743-747.

146. Katz WA, Rothenberg R. The nature of pain: Pathophysiology. J Clin Rheumatol 2005; 11(2 suppl):S11-15.

147. Mao J, Chen LL. Systemic lidocaine for neuropathic pain relief. Pain 2000; 87:7-17.
148. Pasqualucci A. Experimental and clinical studies about the preemptive analgesia with local anesthetics. Possible reasons of the failure. Minerva Anestesiol 1998; 64:445-457.

149. Ferrante FM, Paggioli J, Cherukuri S, Arthru GR. The analgesic response to intravenous lidocaine in the treatment of neuropathic pain. Anesth Analg 1996; 82:91-97.

150. Arner S, Lindblom U, Meyerson BA, Molander $\mathrm{C}$. Prolonged relief of neuralgia after regional anesthetic block. A call for further experimental and systematic clinical studies. Pain 1990; 43:287297.

151. Lavoie PA, Khazen T, Filion PR. Mechanisms of the inhibition of fast axonal transport by local anesthetics. Neuropharmacology 1989; 28:175-181.

152. Bisby MA. Inhibition of axonal transport in nerves chronically treated with local anesthetics. Exp Neurol 1975; 47:481-489.

153. Wertheim HM, Rovenstine EA. Suprascapular nerve block. Anesthesiology 1941; 2:541.

154. Manchikanti L. Interventional pain management: Past, present, and future. The Prithvi Raj lecture: Presented at the 4th World Congress-World Institute of Pain, Budapest, 2007. Pain Pract 2007; 7:357-371.

155. Abram SE, Likavec MJ. Pain syndromes and rationale for management. Neurogenic pain. In: Raj P (ed). Practical Management of Pain. Year Book Medical Publishers, Chicago, 1986, pp 182-191.

156. Manchikanti L, Singh V, Rivera JJ, Pampati V, Beyer CD, Damron KS, Barnhill RC. Effectiveness of caudal epidural injections in discogram positive and negative chronic low back pain. Pain Physician 2002; 5:18-29.

157. Bonica JJ. Current role of nerve blocks in diagnosis and therapy of pain. In: Bonica JJ (ed). Advances in Neurology, Vol. 4. Raven Press, New York, 1974, pp 445-453.

158. Manchikanti L, Pampati V, Rivera JJ, Beyer CD, Damron KS, Barnhill RC. Caudal epidural injections with Sarapin steroids in chronic low back pain. Pain Physician 2001; 4:322-335.

159. Raj PP. Prognostic and therapeutic local anaesthetic blockade. In: Cousins MJ, Bridenbaugh PO (eds). Neural Blockade. Lippincott, Philadelphia, 1988, pp 900-901.

160. Sato C, Sakai A, Ikeda Y, Suzuki H, 
Sakamoto A. The prolonged analgesic effect of epidural ropivacaine in a rat model of neuropathic pain. Anesth Analg 2008; 106:313-320.

161. Manchikanti L, Singh V, Falco FJ, Cash KA, Pampati V. Lumbar facet joint nerve blocks in managing chronic facet joint pain: One-year follow-up of a randomized, double-blind controlled trial: Clinical Trial NCTo0355914. Pain Physician 2008; 11:121-132.

162. Manchikanti L, Singh V, Falco FJ, Cash KA, Fellows B. Cervical medial branch blocks for chronic cervical facet joint pain: A randomized double-blind, controlled trial with one-year follow-up. Spine 2008; 33:1813-1820.

163. Manchikanti L, Singh V, Falco FJE, Cash KA, Pampati V. Effectiveness of thoracic medial branch blocks in managing chronic pain: A preliminary report of a randomized, double-blind controlled trial; Clinical trial NCT00355706. Pain Physician 2008; 11:491-504.

164. Kawakami M, Weinstein JN, Chatani K, Spratt KF, Meller ST, Gebhart GF. Experimental lumbar radiculopathy. Behavioral and histologic changes in a model of radicular pain after spinal nerve root irritation with chromic gut ligatures in the rat. Spine 1994; 19:1795-1802.

165. Manchikanti KN, Pampati V, Damron KS, McManus CD. A double-blind, controlled evaluation of the value of Sarapin in neural blockade. Pain Physician 2004; 7:59-62.

166. Manchikanti L, Damron KS, Cash KA, Manchukonda R, Pampati V. Therapeutic medial branch blocks in managing chronic neck pain: A preliminary report of a randomized, double-blind, controlled trial: Clinical Trial NCTo033272. Pain Physician 2006; 9:333-346.

167. Manchikanti L, Manchikanti KN, Manchukonda R, Pampati V, Cash KA. Evaluation of therapeutic thoracic medial branch block effectiveness in chronic thoracic pain: A prospective outcome study with minimum 1-year follow up. Pain Physician 2006; 9:97-105.

168. Manchikanti L, Manchikanti K, Manchukonda R, Cash KA, Damron KS, Pampati V, McManus CD. Evaluation of lumbar facet joint nerve blocks in the management of chronic low back pain: A preliminary report of a randomized, dou- ble-blind controlled trial: Clinical Trial NCTooo355914. Pain Physician 2007; 10:425-440.

169. Altman DG, Schulz KF, Moher D, Egger M, Davidoff F, Elbourne D, Gøtzsche PC, Lang T; CONSORT GROUP (Consolidated Standards of Reporting Trials). The revised CONSORT statement for reporting randomized trials: Explanation and elaboration. Ann Intern Med 2001; 134:663-694.

170. Piaggio G, Elbourne DR, Altman DG, Pocock SJ, Evans SJ; CONSORT Group. Reporting of noninferiority and equivalence randomized trials: An extension of the CONSORT statement. JAMA 2006; 295:1152-1160.

171. Zwarenstein M, Treweek S, Gagnier JJ, Altman DG, Tunis S, Haynes B, Oxman AD, Moher D; CONSORT group; Pragmatic Trials in Healthcare (Practihc) group. Improving the reporting of pragmatic trials: An extension of the CONSORT statement. BMJ 2008; 337: a2390. 
